\title{
Maxwell Knight Memorial to a herpetologist, naturalist, conservationist and much more
}

\author{
JOHN E. COOPER ${ }^{1 *}$, MARGARET E. COOPER ${ }^{1} \&$ SIMON H. KING ${ }^{2}$ \\ ${ }^{1}$ Wildlife Health, Forensic and Comparative Pathology Services (UK), Norfolk, PE30 5AP, UK \\ 2J. E Haith Ltd, 2 Genesis Way, Europarc, DN37 9TH, UK \\ ${ }^{*}$ Corresponding author e-mail: ngagi2@gmail.com
}

In 1947, Maxwell Knight (1900-1968) was a founding member of the British Herpetological Society (BHS). For the rest of his life, he attended meetings, served on committees and contributed articles, notes and records to its journal. He was well-known as a naturalist, conservationist, broadcaster and writer but he also had an entirely different and secret career. He was a spy-master, and in later years unfounded assertions about his private life stirred up controversy.

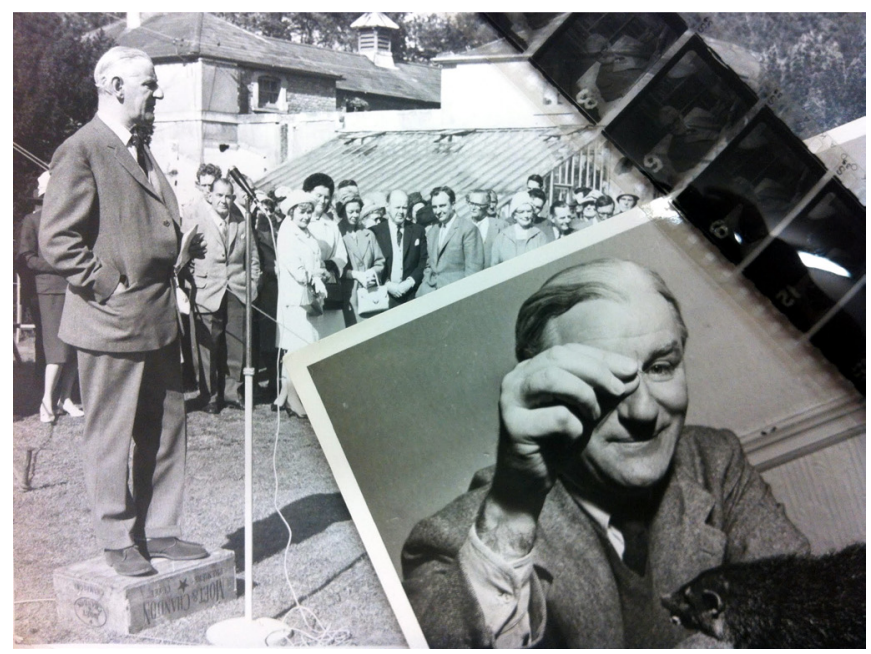

Figure 1. The public face of Maxwell Knight as a naturalist

To mark 50 years since his death, The Maxwell Knight Symposium was held in 2018 under the patronage of the BHS. The account below is based on extracts of the transcripts of talks and submitted notes at the symposium, several of which can be seen on the 'Frightened Face of Nature' (FFON) website (www.ffon.co.uk). These presentations were based on the recollections of eight people who either knew or were influenced by Maxwell Knight (MK): John Cooper, Simon King, John Burton, Norma Chapman, Graham Wellstead, June Chatfield, Mark Rose, and Paul Pearce-Kelly.

As a conservationist MK was a pioneer and contemporary of Peter Scott and his published thoughts are still very relevant. Despite being a spy-master, his greatest fear was not communist Russia but inhumanity to nature; he predicted the wildlife population declines we are experiencing today. This was reinforced recently when an unpublished manuscript, entitled 'The Frightened Face of Nature', was uncovered in Maxwell Knight's cabinet; a very relevant extract that would chime with Greta Thunberg is reproduced in the box opposite.
From Maxwell Knight The Frightened Face of Nature Chapter II - The new approach

In considering the future for wildlife it is vital that the man in the street who, in the long run, will have responsibility for ignoring or fighting for it, should have the point put before him fairly and squarely without his being enveloped in a haze of jargon and technicalities. If he does nothing to help those who are fighting his battles for him at the moment, he will have only himself to blame if his children's children curse him for not being better informed, or for being so gutless that he stood by watching the rape of nature - and did nothing.

Maxwell Knight's hope was that the 'progress at any cost approach' would change, and that industrialised nations would stop playing the short-term natureunfriendly game of habitat destruction so often carried out in the name of progress. Another extract from a chapter of 'The Frightened Face of Nature' illustrates this.

From Maxwell Knight The Frightened Face of Nature Chapter III - The age of science

By all means let man use his great powers to invent new devices; let him give of his best to see that all shall benefit from his genius in curing, healing, and housing those in want. But do not suggest that this can only be done by destroying what is fine to look at or listen to, whether in the arts or nature.

If human brains can find means of defying space, improving means of communication and bouncing pictures off satellites, surely he can also discover ways in which these things can be done without destruction - for destruction first is the cry of mad revolution and is the reverse of evolution.

Maxwell Knight's interest in natural history stemmed from his childhood. He was fascinated by all living things but had a particular love of amphibians and reptiles. Brought up in Mitcham, south London, the young MK had access to the local common and its wildlife and this gave him the opportunity to collect and keep amphibians and reptiles. 
In his early teens MK's father died and an uncle took on responsibility for him. After an undistinguished schooling, he was sent to sea as a naval cadet, at least acknowledging his liking for the outdoor world. Much of his later life was based in London and it was only in his later years that the natural history led to another career overlapping with his MI5 work. During the war and afterwards, he spent most time living away from London in an MI5 safe-house at Camberley, Surrey, and that gave him more scope to keep pets and to develop a series of radio programmes on natural history, later television too, as well as writing.

In 1984, a book entitled, 'The Man Who Was M' was published by Anthony Masters. This contained allegations about homosexuality, bankruptcy, blackmail and illtreatment of his wife. The book caused great distress to those who knew MK and many of these assertions were challenged in a critical review of the book by John Cooper (Cooper, 1986). However, what Anthony Masters did bring to light was previously confidential information about MI5 and the part played by MK before, during, and after the Second World War. MK is believed to have been the model for ' $\mathrm{M}$ ' in lan Fleming's James Bond novels. The revelations about MK's service in the war were a great surprise to many of those who knew him as they were only familiar with his work as a naturalist. And then, in 2017, a further book was published, 'M Maxwell Knight, MI5's Greatest Spymaster', by best-selling non-fiction author and historian Henry Hemming. This lauded MK as a great patriot but also stated that no evidence could be found for the earlier disparaging claims about MK's private life. For more fascinating details and detailed personal recollections, take a look on the internet at 'Maxwell Knight the naturalist' (Cooper, 2018).

Maxwell Knight was MI5's legendary ' $M$ ', a self-taught spymaster who, with the help of young case officers and talented agents, was responsible for counter-subversion and managed successfully to penetrate the British fascist movement and arguably help shorten the Second World War (Andrew, 2009). He was MI5's most gifted agent handler of the inter-war years; his sixth sense for enlisting wouldbe talented agents and officers and developing formal observation training - based on his natural history studies still remains a thing of legend within the Security Services. He championed the recruitment of female agents; broke the Woolwich Arsenal spy case; uncovered a plot to prevent the entry of America into the Second World War and suppressed the fifth column of Nazi sympathisers who were prepared to help pave the way for the occupation of Britain. What made him a talented spymaster and what prepared him for the challenges he faced as ' $M$ ' were his observational skills derived from the study of animal behaviour, and his ability to look deep into nature (Knight, 1960). These talents were honed as a child - inspired by his father - and sharpened by the Boy Scout movement. For more fascinating details take a look on the internet at 'Maxwell Knight the spy-master' (King, 2018).

The conservationist and journalist John Burton had experience of $\mathrm{MK}$ as a broadcaster. His memories of MK began with listening to him participating in the BBC's natural history radio programmes in the late 1940s and the 1950s, such as The Naturalist, Nature Parliament and Naturalists'

\section{From Maxwell Knight 'Animals and Ourselves' (1962)} (Children and Animals)

The great thing to establish, as early as possible, is confidence between children and animals. Nearly all children are interested in and curious about animals; and it is an unusual parent who has not experienced a toddler finding its first earthworm and bringing it in with the question, "What is it?"

Notebook. Then in the 1950s he occasionally found himself participating in programmes presented by MK and so was able to get to know him. On one occasion, in 1959, he spent a day in the field with MK recording material for a programme in The Naturalist series. It was a fine, sunny and very hot day in what was a glorious summer that year. They visited the Plumstead Marshes bordering the River Thames to find and record Britain's bush-crickets and grasshoppers for the programme. It became increasingly overcast with black clouds heralding the arrival of a heavy thunderstorm. MK became anxious to complete their activities before it arrived, apparently because once when he was fishing, his long fishing rod was struck by lightning. Quite understandably, that made him uneasy when lightning threatened. Coincidentally, the Woolwich Arsenal, scene of MK's world-famous break up of a Soviet spy-ring in the 1930s, was sited at the western end of Plumstead Marshes and the programme-making activities described above were in sight of it. John Burton was, of course, unaware then of the part MK had played in that momentous event, but subsequently he imagined that it must have come into MK's mind as they walked along the high outfall sewer bank across the marshes that overlooked the Arsenal.

The closing session of the Commemorative Symposium, 'Newts, Nadders and Neophyte Naturalists', provided entertainment as well as serving as a reminder of the fragility of habitats in Britain, even half a century ago. A team consisting of Simon King, Sarah Pellett, Charles, Rachel and Jonny Foster, Max, Hilda, Margaret and John Cooper re-enacted the 'Surrey Pond Scene' scene, a childhood encounter with youths and newts at a Surrey pond that had been recounted in MK's unpublished book 'The Frightened Face of Nature', found written in his own hand in the filing cabinet - see earlier. The 'Surrey Pond Scene' was beautifully acted out by young naturalists; MK would have approved. Maxwell Knight's name and reputation have been very much resurrected in recent years. Those who attended the Symposium or read this report will, we hope, be encouraged to carry his message forward.

\section{From Maxwell Knight ‘Animals and Ourselves' (1962)}

If one is blessed with some appreciation of scenery; if one can get delight from the songs of birds; if the sight of a butterfly can give pleasure to the eye; then these are additional reasons for desiring and praying that our legislators should, before it is too late, remember that man and animals are not mutually exclusive - or are they? 


\section{ACKNOWLEDGEMENTS}

The Maxwell Knight Commemorative Symposium was planned and organised by the British Herpetological Society (BHS) and generously supported by the British Chelonia Group (BCG), the Amateur Entomologists' Society (AES), the Institute of Animal Technology (IAT) and the Frightened Face of Nature (FFON) and others. The day would not have been such a success without the support of the BHS organising committee, Simon Townson, Paul Eversfield and Mark Hollowell. John Pickett who had been so supportive in the planning stages had greatly looked forward to attending and participating but, alas, that was not to be. It was fitting, therefore, that there was a tribute to John at the beginning of the programme.

\section{REFERENCES}

Andrew, C. (2009). The Defence of the Realm: The Authorised History of MI5. Allen Lane, 1032 pp.
Cooper, J. E. (1986). Book review. The Man who was M. The Life of Maxwell Knight by Anthony Masters. Bulletin of the British Herpetological Society 17: 46-47.

Cooper J.E. (2018). Maxwell Knight the Naturalist. https://thefrightenedfaceofnature.com/maxwell-knightsymposium/lectures/introductory-lecture-maxwellknight-the-naturalist-prof-john-e-cooper/ accessed Oct 2019

Hemming, H. (2017). M Maxwell Knight, MI5's Greatest Spymaster. Preface Publishing, 400 pp.

King S.H. (2018) Maxwell Knight the spy-master. https:// thefrightenedfaceofnature.com/maxwell-knightsymposium/lectures/maxwell-knight-the-spymaster-mrsimon-h-king/ accessed Oct 19

Knight, M. (1962). Animals and Ourselves. Hodder and Stoughton, $160 \mathrm{pp}$.

Knight, M. (1960). The Young Field Naturalist's Guide. G. Bell \& Sons, $144 \mathrm{pp}$.

Masters, A. (1984). The Man Who Was M. The Life of Maxwell Knight. Basil Blackwell, 212 pp.

Accepted: 31 October 2019 